\title{
Testosterone and progesterone concentrations in blow samples are biologically relevant in
} belugas (Delphinapterus leucas)

\author{
Justin T. Richard ${ }^{\mathrm{a}, \mathrm{b}}$, Todd R. Robeck ${ }^{\mathrm{c}}$, Steven D. Osborn ${ }^{\mathrm{d}}$, Lisa Naples ${ }^{\mathrm{e}}$, Alexa McDermott ${ }^{\mathrm{f}}$, \\ Robert LaForge ${ }^{\mathrm{a}}$, Tracy A. Romano ${ }^{\mathrm{b}}$, Becky L. Sartini ${ }^{\mathrm{a}}$
}

Corresponding Author: Justin Richard, jt_richard@uri.edu

Affiliations:

a: University of Rhode Island, 120 Flagg Rd, Kingston, RI 02881, USA

b: Mystic Aquarium, a division of Sea Research Foundation, 55 Coogan Blvd, Mystic, CT

06355, USA

c: SeaWorld and Busch Gardens Reproductive Research Center, SeaWorld Parks and

Entertainment, 2595 Ingraham Road, San Diego, CA 92019, USA

d: SeaWorld San Antonio, 10500 SeaWorld Drive, San Antonio, TX 78251, USA

e: Shedd Aquarium, 1200 S. Lake Shore Drive, Chicago, IL 60605, USA

f: Georgia Aquarium, 225 Baker St. NW, Atlanta, GA 30313, USA 


\begin{abstract}
Steroid hormone analysis in blow (respiratory vapor) may provide a minimally invasive way to assess the reproductive status of wild cetaceans. Biological validation of the method is needed to allow for the interpretation of hormone measurements in blow samples. Utilizing samples collected from trained belugas (Delphinapterus leucas, $\mathrm{n}=20$ ), enzyme immunoassays for testosterone and progesterone were validated for use with beluga blow samples. Testosterone concentrations in 40 matched blood and blow samples collected from 4 male belugas demonstrated a positive correlation $\left(R^{2}=0.52, p<0.0001\right)$. Progesterone concentrations in 64 matching blood and blow samples from 11 females were also positively correlated $\left(R^{2}=0.60, p\right.$ $<0.0001)$. Testosterone concentrations (mean \pm SD) in blow samples collected from adult males $(119.3 \pm 14.2 \mathrm{pg} / \mathrm{ml})$ were higher $(p<0.01)$ than that of a juvenile male $(<8$ years $)(59.4 \pm 6.5$ $\mathrm{pg} / \mathrm{ml})$ or female belugas $(54.1 \pm 25.7 \mathrm{pg} / \mathrm{ml})$. Among adult males, testosterone concentrations in blow demonstrated a seasonal pattern of secretion, with peak secretion occurring during the breeding season (February - April, $136.95 \pm 33.8$ pg/ml). Progesterone concentrations in blow varied by reproductive status; pregnant females $(410.6 \pm 87.8 \mathrm{pg} / \mathrm{ml})$ and females in the luteal phase of the estrous cycle $(339.5 \pm 51.0 \mathrm{pg} / \mathrm{ml})$ had higher $(p<0.0001)$ blow progesterone concentrations than non-pregnant females without a corpus luteum $(242.5 \pm 27.3 \mathrm{pg} / \mathrm{ml})$. Results indicate that blow sample analysis can be used to detect variation in reproductive states associated with large differences in circulating testosterone or progesterone in belugas.
\end{abstract}

Keywords: alternative matrix, noninvasive, testosterone, progesterone, cetacean, beluga 


\section{Introduction}

Reproductive steroid hormone determinations are frequently used to assess the reproductive status of individual animals, yielding information such as sex, maturity status, and reproductive cycle stage. At the population level, this information is necessary to assess demographics and viability and is crucial to the development and long term monitoring of conservation plans (Kersey and Dehnhard, 2014; Labrada-Martagón et al., 2014). For example, the endangered Cook Inlet stock of beluga whales in Alaska (USA) is one such population that will benefit from monitoring reproductive status; improved understanding of the demographics of the population could aid in the identification of factors limiting population recovery (Hobbs et al., 2015).

The utility of reproductive steroid determination in cetaceans has been established using blood samples (e.g. Kellar et al., 2013a; Robeck and Monfort, 2006). While collecting blood samples is complicated by the aquatic environment, advances in the use of minimally invasive alternative matrices (reviewed in Amaral, 2010) has enabled hormone determination research in wild cetaceans that can inform management (Kellar et al., 2009; Kellar et al., 2013b).

To date, the most commonly used matrices for hormone determination in wild cetaceans are blubber samples obtained via remote biopsy sampling (Perez et al., 2011) and fecal samples collected from the water's surface (Rolland et al., 2005). Despite the value of these methodologies, they may not be appropriate for all species or all populations. Biopsy sampling may not be ideal if repeated sampling is required, or if conservation concerns make even small risks to the animal's health undesirable. These risks may limit the sampling population available if investigators are required to avoid sampling mothers with young calves or the calves themselves (Kellar et al., 2014). Defecation is infrequently observed and difficult to collect from 
small cetaceans (Green et al., 2007). Additionally, assigning fecal samples to particular individuals can be difficult in highly social species. These and other limitations in existing methodologies have led to a recent effort to develop "blow" (exhale) sampling as a source of reproductive hormones for analysis in cetaceans.

Blow, which is also referred to as respiratory vapor or exhaled breath condensate, can be collected without establishing contact when the whale surfaces to breathe. Blow samples contain steroid and thyroid hormones at detectable levels, as demonstrated in a variety of cetaceans (Hogg et al., 2005; Hogg et al., 2009; Hunt et al., 2014; Thompson et al., 2014). Due to the minimally invasive nature of this sampling, blow sampling has the potential to be a very useful tool in monitoring cetacean populations and assessing the health and reproductive status of individuals (Hunt et al., 2013).

In order for blow sampling to reach its potential as a diagnostic tool for use in population assessments, the measurement of the various hormones in this matrix must be shown to be physiologically relevant. Testosterone ( 3 species) and progesterone ( 5 species) have been detected in blow samples from both mysticete and odontocete cetaceans (Dunstan et al., 2012; Hogg et al., 2005; Hogg et al., 2009; Hunt et al., 2014; Tizzi et al., 2010). However, without knowledge of how blow hormone concentrations relate to blood concentrations or the reproductive status of an individual, the ability to interpret blow hormone concentrations has mostly been limited to assessing presence or absence. The use of blow as a diagnostic tool will be greatly enhanced if the relationship between hormone concentrations in blow and sex, maturity status, pregnancy status, or breeding season is known.

Belugas are an ideal study species for advancing the use of blow sampling as a diagnostic tool. Their reproductive biology is well understood, due to extensive post-mortem studies from 
subsistence harvests (e.g. Burns and Seaman, 1988; Heide-Jørgensen and Teilmann, 1994; Høier and Heide-Jørgensen, 1994) as well as in depth longitudinal studies of live animals conducted in aquaria (e.g. Robeck et al., 2005; Steinman et al., 2012). Belugas are widely held under professional managed care, making it possible to collect sufficient blow samples from known individuals to develop hormone assays and to sample the same individuals longitudinally to assess changes in reproductive status over time. Although reproductive steroids have not been measured in beluga blow samples, blow sampling has already been shown to be an effective way to assess cortisol secretion in this species (Thompson et al., 2014). There is also potential to apply the methodology to wild belugas (Thompson et al., 2014), as well as a need for additional information to improve management (National Marine Fisheries Service, 2015).

The aim of this study was to determine if testosterone and progesterone concentrations in beluga blow samples are biologically relevant, laying the foundation for the development of blow sampling as a diagnostic tool in this species. The specific objectives were to validate commercially available enzyme immunoassays for testosterone and progesterone in beluga blow samples and to demonstrate the physiological relevance of hormone concentrations in blow through comparison with matched blood samples collected from animals of different sex, age and reproductive status. Finally, to evaluate the applicability of these techniques toward wild populations, we measured and compared testosterone concentrations in matched blow and serum samples from estimated aged wild belugas.

\section{Methods}

\subsection{Study animals and sample collection}

\subsubsection{Aquaria}


All blow and blood samples were collected via trained behaviors. Blow samples were collected from a total of 20 belugas ( 8 male, 12 female) from four different aquaria, ranging in age from 3-33 years (Table 1). Males less than 8 years old and females less than 6 years old were considered juveniles (Robeck et al., 2005). Belugas were housed in mixed sex groups with at least 2 males. Three of the four adult males sampled were proven sires. To assess seasonality of testosterone secretion, two males were sampled in all 12 calendar months, and all males were sampled between February and April, representing much of the period of peak testosterone secretion in belugas (January - April, Robeck et al., 2005). This project was approved by the Institutional Animal Care and Use Committees of Mystic Aquarium (Project \#12001) and the University of Rhode Island (Project \#AN12-02-016).

\subsubsection{Ultrasonography and Characterization of Reproductive Status in Adult Females}

To monitor for pregnancy, ultrasound exams were conducted on female belugas approximately twice per month at irregular intervals that varied by individual. Ultrasound exams were performed on belugas trained to lie unrestrained in lateral recumbency at the water's surface. Females were retrospectively confirmed pregnant based on visual detection of uterine fluid with fetal membranes and or a fetus (Robeck et al., 2015). The presence of a corpus luteum (CL) was detected via ovarian ultrasound or inferred by high progesterone levels in blood (>3 ng/ml) (Robeck et al., 2010). However, blow samples were collected more frequently than other physiological assessments. This necessitated the inference of the presence or absence of a CL, using the known estrous cycle length in belugas, in order to correctly group blow samples by the female's reproductive condition. For females retrospectively confirmed to be pregnant, the CL was presumed to have been present for 30 days prior to the pregnancy diagnosis. For non- 
pregnant females, the CL was presumed to persist for 14 days following detection (Robeck et al., 2010; Steinman et al., 2012).

\subsubsection{Blow sample collection}

Blow samples were collected onto a nylon mesh $(110 \mu \mathrm{m}$, Elko Filtering Co., Miami, FL) stretched over a petri dish (100 mm diameter) and secured with a rubber band (Thompson et al., 2014). The nylon mesh and rubber bands were cleaned prior to use by soaking in $70 \%$ ethanol for $15 \mathrm{~min}$, rinsed with Nanopure water, and air dried. For sample collection, the whales were trained to lift their head so that the blowhole was above the water's surface. Whales were trained to exhale once to clear any excess water from the blowhole surface. Then, 2-8 successive exhales were collected onto the mesh which was held at an approximate distance of $10 \mathrm{~cm}$ above the blowhole. The nylon was used to soak up any fluid that may have passed through onto the petri dish, and was immediately put into a $15 \mathrm{ml}$ conical tube pre-loaded with half of a plastic syringe stopper in the bottom. The syringe stopper allowed for later centrifugation of the nylon to retrieve the fluid blow sample. This tube was then frozen within $10 \mathrm{~min}$ at $-20^{\circ} \mathrm{C}$ and stored for up to 2 weeks until processing, or at $-80^{\circ} \mathrm{C}$ until shipment on dry ice to the laboratory.

To retrieve the respiratory vapor, the tubes were thawed for $15 \mathrm{~min}$ and centrifuged at $10^{\circ}$ $\mathrm{C}$ for $30 \mathrm{~min}$ at $2600 \times \mathrm{g}$. The volume of each sample was recorded and the fluid was frozen in $1.5 \mathrm{ml}$ cryovials at $-80^{\circ} \mathrm{C}$ until analysis. 
Table 1. Samples used for hormone analysis from aquarium belugas.

\begin{tabular}{|c|c|c|c|c|c|c|c|}
\hline ID \# & Sex & $\begin{array}{c}\text { Maturity and } \\
\text { Reproductive Status }\end{array}$ & $\begin{array}{c}\text { Blow Samples } \\
\text { Assayed for } \\
\text { Testosterone }\end{array}$ & $\begin{array}{c}\text { Blood } \\
\text { Samples } \\
\text { Assayed for } \\
\text { Testosterone } \\
\end{array}$ & $\begin{array}{c}\text { Months } \\
\text { Sampled for } \\
\text { Testosterone }\end{array}$ & $\begin{array}{c}\text { Blow } \\
\text { Samples } \\
\text { Assayed for } \\
\text { Progesterone }\end{array}$ & $\begin{array}{c}\text { Blood } \\
\text { Samples } \\
\text { Assayed for } \\
\text { Progesterone }\end{array}$ \\
\hline DL1 & Male & Adult, proven sire & 55 & 10 & Jan - Dec & 4 & - \\
\hline DL2 & Male & Adult & 28 & 20 & Jan - Dec & 3 & - \\
\hline DL3 & Male & Adult, proven sire & 7 & 7 & Feb - Aug & 4 & - \\
\hline DL4 & Male & Adult, proven sire & 4 & - & Feb - Jun & 0 & - \\
\hline DL5 & Male & Juvenile & 3 & 3 & Feb-Apr & 3 & - \\
\hline DL6 & Male & Juvenile & 2 & - & Jan - Feb & 1 & - \\
\hline DL7 & Male & Juvenile & 2 & - & Mar, Dec & 1 & - \\
\hline DL8 & Male & Juvenile & 5 & - & Feb - Jun & 3 & - \\
\hline DL9 & Female & Juvenile & 2 & - & Feb, May & 5 & 1 \\
\hline DL10 & Female & Adult & 1 & - & Feb & 3 & 0 \\
\hline DL11 & Female & Adult, became pregnant & 1 & - & May & 12 & 2 \\
\hline DL12 & Female & Adult, became pregnant & 2 & - & May, Jul & 67 & 14 \\
\hline DL13 & Female & Adult & 1 & - & May & 7 & 4 \\
\hline DL14 & Female & Adult & 4 & - & Jun-Jul & 22 & 14 \\
\hline DL15 & Female & Adult & 4 & - & Jun - Oct & 10 & 2 \\
\hline DL16 & Female & Adult, became pregnant & 1 & - & Jun & 22 & 14 \\
\hline DL17 & Female & Adult & 2 & - & Feb, Apr & 3 & 2 \\
\hline DL18 & Female & Adult & 2 & - & Feb, Apr & 6 & 4 \\
\hline DL19 & Female & Adult & - & - & - & 4 & 1 \\
\hline \multirow[t]{2}{*}{ DL20 } & Female & Juvenile & - & - & - & 6 & 6 \\
\hline & & Total & 126 & 40 & & 186 & 64 \\
\hline
\end{tabular}

* Belugas were housed at: Georgia Aquarium, Atlanta; Mystic Aquarium, Mystic, CT; Shedd Aquarium, Chicago, IL; SeaWorld, San Antonio, TX 
When possible, blood samples were collected into serum separator or sodium heparinized vacutainer tubes within one hour of blow sampling from a ventral fluke vein via trained behavior as a part of routine veterinary monitoring. Matching blood and blow samples were collected in the morning hours, typically between 0900 and 1000 hours. One $\mathrm{ml}$ of serum or sodium heparin plasma was obtained through centrifugation $\left(2000 \times \mathrm{g}\right.$ for $10 \mathrm{~min}$ at $10^{\circ} \mathrm{C}$ ) and stored at $-80^{\circ} \mathrm{C}$.

\subsubsection{Bristol Bay, Alaska}

Blow samples were collected from 10 wild belugas ( 8 males and 2 females) in Bristol Bay, Alaska between August 25 and September 2, 2014 while they were temporarily restrained for health assessment and satellite tagging (described in Norman et al., 2012). Samples were collected under National Marine Fisheries Service Marine Mammal Research Permit \#14245. Animals were sexed and judged to be mature adults based on growth curves for this stock (Suydam, 2009). Four exhales were collected per sample as described above, but due to field conditions it was not always possible to ensure that the blowhole was free of all water prior to collecting an exhale as it was with aquarium belugas. Once sealed inside a $15 \mathrm{ml}$ conical tube, the samples were stored in a cooler on ice packs for 2-6 hours prior to centrifugation. The volume of each sample was measured and the fluid was transferred to $1.5 \mathrm{ml}$ cryovials tubes for storage. The samples were frozen in liquid nitrogen within 8 hours of collection. Blood samples were also collected from the same individual, centrifuged to obtain sodium heparin plasma, and stored in a liquid nitrogen dry shipper for transport.

\subsection{Enzyme Immunoassay Validations}


Commercially available enzyme immunoassays (Cayman Chemical, Ann Arbor, MI, Items \#582701 and \#582601 for testosterone and progesterone, respectively) were validated for use with beluga blow, serum, and plasma. All blood samples were extracted prior to assay per the EIA kit manufacturer's instructions (testosterone: diethyl ether, progesterone: dichloromethane; Sigma-Aldrich, St. Louis, MO, Catalog \#346136 and \#270997 respectively). Blow samples were assayed for testosterone without an extraction step. Untreated blow samples assayed for progesterone displayed parallelism to the standard curve, but failed the accuracy test, indicating matrix interference. Four extraction protocols for the extraction of progesterone from various matrices were tested in preliminary experiments (dichloromethane liquid-liquid microextraction and 3 variations of a solid phase extraction protocol) and all failed either parallelism or accuracy tests (data not shown). A diethyl ether liquid-liquid extraction was considered optimal (see Results) and used for all samples. Samples (55 or $60 \mu 1)$ were placed in glass test tubes and $0.5 \mathrm{ml}$ of diethyl ether was added. The samples were vortexed for $2 \mathrm{~min}$, and then the aqueous layer was frozen in an ultralow freezer. The ether layer was poured off and the extraction procedure was repeated. The two ether layers were combined, dried under compressed air, and reconstituted in 110 or $120 \mu$ of assay buffer (for a final dilution of 1:2).

Parallelism to the standard curve was tested for blow, serum, and plasma using pooled male samples for testosterone and pooled female samples for progesterone. Accuracy was tested for blow, serum, and plasma using pooled samples spiked with an equal volume of known amounts of standard. Extraction efficiency in blood samples was tested by adding a known amount of hormone to subsamples of unextracted sample pools and performing the extraction protocol. Extraction efficiency was calculated as the observed amount of hormone quantified in the assay divided by the total amount of hormone expected (native testosterone present in 
unspiked sample plus amount of spiked testosterone) multiplied by 100 . To test for assay interference and recovery from the collection material, nylon mesh was spiked with assay buffer (negative control; $n=10$ for testosterone, $n=4$ for progesterone) or known concentrations of hormone in three replicates. The spiked nylon was treated identically to a biological sample (placed in $15 \mathrm{ml}$ conical tube, frozen $>24$ hours, thawed, centrifuged to recover spiked fluid, and refrozen until assay). Hormone recovery (observed divided by expected multiplied by 100) was measured. Validation procedures that varied by sample type are presented in Table 2.

Table 2. Validation experiment details.

\begin{tabular}{|c|c|c|c|c|}
\hline \multirow[b]{2}{*}{ Procedure } & \multicolumn{2}{|c|}{ Testosterone } & \multicolumn{2}{|c|}{ Progesterone } \\
\hline & Blow & $\begin{array}{l}\text { Serum and } \\
\text { Plasma }\end{array}$ & Blow & $\begin{array}{l}\text { Serum and } \\
\text { Plasma }\end{array}$ \\
\hline Dilutions used in parallelism test & $\begin{array}{c}\text { Serially } \\
\text { diluted, neat } \\
\text { to } 1: 16\end{array}$ & $\begin{array}{l}1: 10,1: 20 \\
1: 40,1: 60 \\
1: 80,1: 100\end{array}$ & $\begin{array}{c}\text { Serially } \\
\text { diluted, neat } \\
\text { to } 1: 8\end{array}$ & $\begin{array}{l}1: 10,1: 20 \\
1: 40,1: 60 \\
1: 80\end{array}$ \\
\hline Dilution used to test accuracy & $1: 2$ & $1: 20$ & $1: 2$ & $1: 40$ \\
\hline $\begin{array}{l}\text { Spiked concentrations used in } \\
\text { accuracy test }(\mathrm{pg} / \mathrm{ml})\end{array}$ & $\begin{array}{l}125,62.5 \\
31.3,15.6 \\
7.8\end{array}$ & $\begin{array}{c}125,62.5 \\
31.3,15.6,7.8\end{array}$ & $\begin{array}{c}250,125 \\
62.5,31.25 \\
15.625\end{array}$ & $\begin{array}{l}500,250 \\
125,62.5 \\
31.25\end{array}$ \\
\hline $\begin{array}{l}\text { Spiked amount of hormone used } \\
\text { for extraction efficiency test (pg) }\end{array}$ & N/A & $\begin{array}{l}0,250,500 \\
1000,2000\end{array}$ & $\begin{array}{c}0,500,1000 \\
2000,4000\end{array}$ & $\begin{array}{c}0,500 \\
1000,2000 \\
4000\end{array}$ \\
\hline $\begin{array}{l}\text { Spiked amount of hormone used } \\
\text { to test recovery from the nylon } \\
\text { collection material (pg) }\end{array}$ & $\begin{array}{c}0,7.8,15.6 \\
31.3,62.5 \\
125,250\end{array}$ & N/A & $\begin{array}{l}125,250 \\
500,1000\end{array}$ & N/A \\
\hline
\end{tabular}

\subsection{Hormone Assay}

Blow samples were centrifuged at 8,000 $x \mathrm{~g}$ for $10 \mathrm{~min}$ to remove particulates prior to extraction or assay, and were assayed at 1:2 dilution. All samples were assayed in duplicate and the means were used in calculations. Individual samples with a $\% \mathrm{~B} / \mathrm{B}_{\mathrm{o}}$ between 20 and $80 \%$ and a coefficient of variation $(C V)<20 \%$ were accepted. Samples with CV $>20 \%$ were re-assayed, and blood samples outside of the range of the kit were re-assayed at a different dilution. Two female blow samples assayed for testosterone had CV above the 20\% cutoff (24.2 and 23.1), but 
were kept in the analysis due to lack of volume to re-run the assay for these samples. Blood samples with low progesterone $(<300 \mathrm{pg} / \mathrm{ml})$ were prone to higher $\mathrm{CV}$; if re-assaying these samples did not result in a CV below the $20 \%$ threshold, the concentration measurement with the lowest $\mathrm{CV}$ was used for analysis $(n=8)$. Two standard controls were run in each assay (testosterone: 100 and $25 \mathrm{pg} / \mathrm{ml}, n=12$; progesterone: 200 and $50 \mathrm{pg} / \mathrm{ml}, n=14$ ). Inter-assay variation was calculated by determining the $\mathrm{CV}$ for the two standard controls on each plate. Intra-assay variation was calculated by averaging the CV for all of the samples with 20-80\% binding on each plate.

\subsection{Sample handling and storage}

To test the effect of long term storage on testosterone concentration in blow, a pool of male blow samples was aliquoted into 5 separate cryovial tubes and stored at $-80^{\circ} \mathrm{C}$. The pool was assayed 2 days after construction, then again 3, 17, 20, and 21 months later.

To determine if temporary chilled storage used during field work influenced testosterone concentration in blow, a separate pool of male blow samples was aliquoted in duplicate into 12 separate cryovial tubes. Two aliquots were frozen immediately and replicate aliquots were stored in a cooler on ice packs for $2,4,6,8$, and 10 hours before freezing at $-80{ }^{\circ} \mathrm{C}$ to simulate field conditions. Both replicates from the 0 hour time point (frozen immediately) from this experiment had an unacceptable CV (>30\%), so another experiment was conducted to examine the time between 0 and 2 hours. For this experiment, a third pool of male blow samples was aliquoted in duplicate into separate cryovial tubes; 2 samples were frozen at $-80{ }^{\circ} \mathrm{C}$ immediately after construction, the others were stored in a cooler on ice packs for 30, 60, 90, and 120 min. The cooler remained at $4-7^{\circ} \mathrm{C}$ for the duration of these experiments. 
To test the effect of the freeze-thaw-freeze cycle that blow samples in this study were subjected to on testosterone concentration in blow, a pool of male blow samples was aliquoted into 4 cryovial tubes. One aliquot was frozen at $-80{ }^{\circ} \mathrm{C}$ immediately (no subsequent thawfreeze), while the other aliquots were stored in a $-20^{\circ} \mathrm{C}$ freezer for 1,2 , or 4 weeks. After the appropriate duration, they were thawed and refrozen at $-80{ }^{\circ} \mathrm{C}$ until analysis.

To assess within sample variation, samples were collected on two separate collection devices; the first contained the blow from the first, third, and fifth exhale, while the second contained the blow from the second, fourth, and sixth exhale. A total of five samples collected in this manner from two different males were assayed for testosterone. To explore the influence that centrifugation might have on testosterone measurements, 4 samples from a male beluga were divided into two subsamples. One subsample was centrifuged prior to being assayed as described above, while the other was mixed thoroughly prior to being assayed.

\subsection{Statistics}

All statistical analyses were performed in R (R Core Team, 2015). Linear regression models (ANCOVA) were used to test for parallelism between serially diluted sample pools and the standard curve. Accuracy was tested by linear regression and considered acceptable if the slope of the line was not significantly different from 1 . Linear regression was used to test for the effect of sample volume or sample handling regime on testosterone concentration. Assessing the correlation between hormone concentrations measured in blow and matching blood samples in aquarium belugas using linear regression required hormone concentrations to be log transformed to meet normality assumptions; Bristol Bay beluga blood and blow testosterone concentrations were correlated separately and were not transformed. For aquarium belugas with more than 5 
matched observations, each individual's correlation was examined separately to account for the uneven number of samples available from each beluga.

To describe seasonality of testosterone concentrations in blow collected from adult males, an additive modeling approach was used to identify the polynomial regression model that best described the data using a centered time variable (month). Random intercept and random slope terms were tested to account for observations being clustered by individual using the $\{1 \mathrm{lme} 4\}$ package in R (Bates et al., 2015). Model fits were compared using ANOVA, AIC, and LogLikelihood.

To test for differences in log transformed blow testosterone concentrations in belugas with varying sex and reproductive status, mixed effects regression models were constructed using the predictors of sex, status (adult or juvenile), and season (Feb - Apr or May - Jan). To account for clustered observations within individual, a random intercept term was incorporated into the model. Significant interaction terms were evaluated graphically by constructing effects plots using the \{effects $\}$ package in R (Fox, 2003). The same method was used for log transformed progesterone concentrations in blow, using a predictor combining females with a corpus luteum or a pregnancy as well as a random intercept term. Males were left out of the model to avoid multicollinearity between sex and luteal activity and pregnancy, and thus sex differences in blow progesterone concentrations will not be interpreted. Means are presented \pm 1 $\mathrm{SD}$ and significance levels were set at $p<0.05$.

\section{Results}

The number of exhales collected per sampling event (mean \pm SD) was $4.2 \pm 0.9$ for aquarium males, $5.5 \pm 2.0$ for aquarium females, and $4 \pm 0$ for Bristol Bay belugas. The blow 
sample volume per exhale (mean $\pm \mathrm{SD}, \mu \mathrm{l}$ ) was $78 \pm 44$ for aquarium males, $57 \pm 50$ for aquarium females, and $63 \pm 40$ for Bristol Bay belugas.

\subsection{Testosterone Assay Validation}

The binding of a serially diluted pool of male blow samples was parallel to the standard curve $\left(F_{1,7}=0.64, p=0.45\right)$. Testosterone was detectable in the sample pool for dilutions from neat to 1:16. The recovery of testosterone from spiked blow sample pools was $102 \pm 7 \%(\mathrm{y}=$ $\left.1.02 \mathrm{x}-0.20, R^{2}=.99\right)$. The slope of the regression line was not significantly different from 1 (95\% CI $[0.94,1.10])$, demonstrating good accuracy.

A low level of testosterone was recovered from negative control nylon spiked with assay buffer $(n=10,45.02 \pm 11.23 \mathrm{pg} / \mathrm{ml})$. The nylon collection material did not interfere with the recovery of known amounts of testosterone, after subtracting the mean blank concentration of 45.02 from each observed concentration $\left(y=0.9756 \mathrm{x}-1.6594, R^{2}=0.99\right)$. Results are reported uncorrected.

Serially diluted pools of extracted serum $\left(F_{1,11}=1.26, p=0.29\right)$ and plasma $\left(F_{1,11}=\right.$ $0.14, p=0.72$ ) displayed binding parallel to the standard curve. Testosterone recoveries from spiked extracted serum $\left(\mathrm{y}=0.91 \mathrm{x}-8.42, R^{2}=0.99,95 \% C I[0.68,1.11]\right)$ and extracted plasma $\left(\mathrm{y}=0.88 \mathrm{x}+6.68, R^{2}=0.97,95 \% C I[0.63,1.10]\right)$ demonstrated good accuracy. The extraction efficiency for serum ranged from $88.3 \%$ to $109 \%$, with a mean of $96.5 \%$. The extraction efficiency for plasma ranged from $69.5 \%$ to $97.9 \%$, with a mean of $79.2 \%$.

The average lower limit of detection $\left(80 \% \mathrm{~B} / \mathrm{B}_{\mathrm{o}}\right)$ was $10.7 \mathrm{pg} / \mathrm{ml}$. Intra-assay variation was $8.37 \%$; inter-assay variation was $6.3 \%$ for the $100 \mathrm{pg} / \mathrm{ml}$ control and $10.3 \%$ for the $25 \mathrm{pg} / \mathrm{ml}$ control. 


\subsection{Progesterone Assay Validation}

The binding of a serially diluted pool of ether extracted female blow samples was parallel to the standard curve $\left(F_{1,6}=0.05, p=0.83\right)$. Progesterone was detectable in the sample pool for dilutions from neat to 1:8. The recovery of progesterone from spiked blow sample pools was $102 \pm 17 \%\left(\mathrm{y}=1.06 \mathrm{x}-5.62, R^{2}=.97\right)$. The slope of the regression line was not significantly different from 1 (95\% CI $[0.74,1.37])$, demonstrating good accuracy. The extraction efficiency for blow ranged from $100 \%$ to $117 \%$, with a mean of $110 \%$.

Progesterone was recovered from negative control nylon spiked with assay buffer $(n=4$, $118.80 \pm 29.80 \mathrm{pg} / \mathrm{ml})$. After subtracting the mean negative control concentration of 118.80 from each observation, the mean recovery of progesterone off of the nylon collection material was $77.68 \%$, and was consistent across the concentrations tested $\left(\mathrm{y}=0.65 \mathrm{x}+71.11, R^{2}=0.99\right)$. Results are reported uncorrected.

Serially diluted pools of extracted serum $\left(F_{1,9}=1.15, p=0.31\right)$ and plasma $\left(F_{1,7}=0.83\right.$, $p=0.39)$ displayed binding parallel to the standard curve. Progesterone recoveries from spiked extracted serum $\left(\mathrm{y}=0.95 \mathrm{x}-26.94, R^{2}=0.998,95 \% C I[0.86,1.03]\right)$ and extracted plasma $(\mathrm{y}=$ $\left.0.93 \mathrm{x}-7.67, R^{2}=0.997,95 \% C I[0.83,1.02]\right)$ demonstrated good accuracy. The extraction efficiency for serum ranged from $97.4 \%$ to $115.3 \%$, with a mean of $105.7 \%$. The extraction efficiency for plasma ranged from $119.2 \%$ to $130.3 \%$, with a mean of $124.4 \%$. The artificial inflation of plasma measurements will not affect the interpretation of the data in this study, as blood sample type was consistent throughout the study by individual (plasma was only collected from DL14, DL15, DL17, DL18, and DL19), most of the samples assayed were serum (44/64), and all of the samples from belugas that became pregnant during the study were serum samples. 
The average lower limit of detection $\left(80 \% \mathrm{~B} / \mathrm{B}_{\mathrm{o}}\right)$ was $32.6 \mathrm{pg} / \mathrm{ml}$. Intra-assay variation was $10.9 \%$; inter-assay variation was $6.6 \%$ for the $200 \mathrm{pg} / \mathrm{ml}$ control and $11.3 \%$ for the $50 \mathrm{pg} / \mathrm{ml}$ control.

\subsection{Sample Handling Experiments}

Storage of a pooled blow sample at $-80^{\circ} \mathrm{C}$ for up to 21 months did not affect testosterone concentration beyond the inter-assay variation $\left(\mathrm{CV}=7.6, F_{1,3}=1.82, p=0.27\right)$. The initial experiment testing the effects of storage in a cooler on testosterone concentration showed a significant effect of storage time on concentration $\left(F_{1,10}=7.87, p=0.02\right)$. The CV for the 12 measurements of the same pool was $17 \%$. However, both replicates of the 0 hours time point had high CV (34 and 36\%). After dropping this time point, storage in a cooler for 2-10 hours before freezing did not significantly affect testosterone concentration $\left(F_{1,8}=0.51, p=0.50\right)$; the $\mathrm{CV}$ for the 10 measurements of the same pool was 5.3\%. A second experiment evaluated the effect of storage time on testosterone concentration from 0-2 hours more closely. Storage on ice packs for up to 2 hours did not affect testosterone concentration $\left(F_{1,8}=2.14, p=0.18\right)$; the $\mathrm{CV}$ for the 10 measurements was $6.5 \%$. Performing a thaw-freeze cycle after 1, 2, or 4 weeks at $20^{\circ} \mathrm{C}$ did not affect testosterone concentration $\left(F_{1,2}=1.37, p=0.36\right)$, with the 8 measurements of the same pool having a $\mathrm{CV}$ of $5.8 \%$.

For samples that were collected onto two separate collection devices, the average CV for the two samples for each divided sample was 9.0\%. For samples that were divided and either centrifuged or mixed prior to assay, the average $\mathrm{CV}$ for the two samples for each divided sample was $6.6 \%$. Sample volume was unrelated to testosterone concentration in male samples $\left(F_{1,104}=\right.$ 2.69, $p=0.1)$. 


\subsubsection{Assay of individual samples: Testosterone}

Testosterone assay results are summarized in Table 3. Blow testosterone concentration was greater than the mean negative control concentration $(45.0 \mathrm{pg} / \mathrm{ml})$ for $90 \%(122 / 136)$ of the biological samples. Of those that were less than the mean negative control concentration, 7 were from females, two were from juvenile males, and 5 were from adult males. Two biological samples (both female) had testosterone concentrations lower than the lowest negative control sample $(27.7 \mathrm{pg} / \mathrm{ml})$.

\subsubsection{Relationship between blood and blow}

There was a significant positive correlation between matching log transformed blow and blood testosterone concentrations from aquarium belugas (Table 4). After correcting for the mean negative control value and removing two observations with negative concentrations, blow testosterone concentration was $4.9 \pm 4.7 \%$ of the matching blood concentration. 
Table 3. Blood and blow testosterone concentrations ( $\mathrm{pg} / \mathrm{ml}$ ) by sex, maturity status, season, and location.

\begin{tabular}{|c|c|c|c|c|c|c|c|c|}
\hline \multirow[b]{2}{*}{ Source } & \multicolumn{4}{|c|}{ Blood Testosterone } & \multicolumn{4}{|c|}{ Blow Testosterone } \\
\hline & $n$ & $\begin{array}{c}\# \\
\text { Samples }\end{array}$ & $\begin{array}{c}\text { Blood } \\
\text { Testosterone } \\
(\text { Mean } \pm \text { SD }) \\
\end{array}$ & $\begin{array}{c}\text { Blood } \\
\text { Testosterone } \\
\text { Range } \\
\end{array}$ & $n$ & $\begin{array}{c}\# \\
\text { Samples }\end{array}$ & $\begin{array}{c}\text { Blow } \\
\text { Testosterone } \\
\text { (Mean } \pm \text { SD) } \\
\end{array}$ & $\begin{array}{c}\text { Blow } \\
\text { Testosterone } \\
\text { Range } \\
\end{array}$ \\
\hline $\begin{array}{l}\text { Aquarium Adult } \\
\text { Male } \\
\text { (all } \\
\text { observations) }\end{array}$ & 3 & 37 & $2462.4 \pm 644.6$ & $214.8-6853.5$ & 4 & 94 & $119.3 \pm 14.2$ & $37.1-244.7$ \\
\hline $\begin{array}{c}\text { Aquarium Adult } \\
\text { Male } \\
\text { (Feb - Apr })\end{array}$ & 3 & 13 & $4024.4 \pm 836.0$ & $933.8-6853.5$ & 4 & 31 & $136.95 \pm 33.8$ & $66.29-244.7$ \\
\hline $\begin{array}{c}\text { Aquarium Adult } \\
\text { Male } \\
\text { (May - Jan) }\end{array}$ & 3 & 24 & $1607.0 \pm 518.3$ & $214.8-5897.0$ & 4 & 63 & $99.4 \pm 39.5$ & $37.1-226.1$ \\
\hline $\begin{array}{c}\text { Aquarium } \\
\text { Juvenile Male }\end{array}$ & 1 & 3 & $114.3 \pm 21.6$ & $89.9-131.1$ & 4 & 12 & $59.4 \pm 6.5$ & $30.28-92.3$ \\
\hline $\begin{array}{l}\text { Aquarium } \\
\text { Female }\end{array}$ & 0 & 0 & -- & -- & 10 & 20 & $54.1 \pm 25.7$ & $21.5-101.1$ \\
\hline $\begin{array}{c}\text { Bristol Bay } \\
\text { Male }\end{array}$ & 8 & 8 & $2195.9 \pm 902.9$ & $932.6-3560.3$ & 8 & 8 & $90.8 \pm 33.5$ & $50.4-145.9$ \\
\hline $\begin{array}{l}\text { Bristol Bay } \\
\text { Female }\end{array}$ & 2 & 2 & & $126.1 ; 175.3$ & 2 & 2 & & $62.5 ; 44.7$ \\
\hline
\end{tabular}

*For aquarium whales sampled more than once, means were first determined for each individual; the data displayed is the mean of the individual means. 
Table 4. Correlation between blood and matching blow sample testosterone concentrations. Individual correlations are shown for belugas with $>5$ observations.

\begin{tabular}{cccccc}
\hline ID & Observations & $\begin{array}{c}\text { Linear } \\
\text { Equation }\end{array}$ & $\boldsymbol{R}^{2}$ & $\boldsymbol{F}(\boldsymbol{d} \boldsymbol{f})$ & $\boldsymbol{p}$ \\
\hline $\begin{array}{c}\text { DL1, DL2, } \\
\text { DL3, DL5 }\end{array}$ & 40 & $\begin{array}{c}\mathrm{y}=0.30 \mathrm{x}+ \\
1.07\end{array}$ & 0.52 & $41.7(1,38)$ & $<0.0001$ \\
\hline DL1 & 10 & $\begin{array}{c}\mathrm{y}=0.35 \mathrm{x}+ \\
0.90\end{array}$ & 0.58 & $10.83(1,8)$ & 0.01 \\
\hline DL2 & 20 & $\begin{array}{c}\mathrm{y}=0.39 \mathrm{x}+ \\
0.79\end{array}$ & 0.50 & $18.28(1,18)$ & $<0.001$ \\
\hline DL3 & 7 & $\mathrm{y}=-0.05 \mathrm{x}+$ & 0.01 & $0.07(1,5)$ & 0.80 \\
\hline
\end{tabular}

\subsubsection{Biological Relevance of Testosterone Concentrations in Blow}

Seasonality of testosterone secretion was found in adult male blow samples. Variation in log transformed testosterone concentrations by month was best described by a quartic polynomial function with a random intercept term $\left(y=-.0843 x+0.0096 x^{2}+0.0033 x^{3}-\right.$ $\left.0.0004 \mathrm{x}^{4}+1.9615\right)($ Fig 1$)$. A comparison between samples from belugas with varying sex and reproductive status showed a significant effect of individual (intercept, $p<0.001$ ), as well as significant interactions between sex and status (adult or juvenile) $(p<0.01)$ and between sex and season (Feb - Apr or May - Jan) $(p<0.001)$. Interpretation of the corresponding effects plots (not shown) demonstrated that adult males had higher testosterone in blow than juvenile males or females, and that adult males sampled during breeding season had higher testosterone concentrations in blow than all other groups. Variation in blow testosterone concentrations by sex and reproductive status is shown in Fig. 2, with negative control data (reported in section 3.1) for comparison.

\subsubsection{Pilot data from wild belugas}


There was no significant relationship between blood and blow testosterone for belugas from Bristol Bay $\left(R^{2}=0.09, F_{1,8}=0.79, p=0.40\right)$. Blow testosterone concentrations were $3.3 \pm$ $3.1 \%$ of those in the matching blood sample. Three male samples exceeded $100 \mathrm{pg} / \mathrm{ml}$; all six animals with blow testosterone concentrations $>65 \mathrm{pg} / \mathrm{ml}$ were male.

\subsubsection{Assay of individual samples: Progesterone}

Progesterone results are summarized in Table 5. All blow samples had concentrations higher than the mean negative control samples; two samples had concentrations lower than the highest negative control sample $(151.7 \mathrm{pg} / \mathrm{ml})$.

\subsubsection{Relationship between Blood and Blow}

There was a significant positive correlation between matching log transformed blow and blood progesterone concentrations from aquarium belugas (Table 6). After correcting for the mean negative control value, blow progesterone concentration was $3.3 \pm 1.4 \%$ of the matching blood concentration for pregnant females and $44.3 \pm 31.3 \%$ of the matching blood concentration for non-pregnant females.

\subsubsection{Biological Relevance of Progesterone Concentrations in Blow}

Pregnant belugas and belugas with luteal activity had higher progesterone concentrations in blow than females without luteal activity or ongoing pregnancies $(p<0.0001)$ (Fig. 3). A blow concentration $>330 \mathrm{pg} / \mathrm{ml}$ was a valuable diagnostic threshold: $6 \%$ of the blow samples collected from non-pregnant females and $80 \%$ of the blow samples collected from pregnant females or females in the luteal phase had progesterone concentrations that exceeded $330 \mathrm{pg} / \mathrm{ml}$. Only pregnant belugas had progesterone concentrations in blow $>420 \mathrm{pg} / \mathrm{ml}$. All three belugas 
that were pregnant during the study demonstrated temporal variation that was associated with changes in pregnancy status (Fig. 4). Although samples collected while a CL was active were rare (4 from DL12, 2 from DL16, and 6 from DL14), blow progesterone concentrations were higher than in females without luteal activity, and longitudinal variation in blow progesterone was observed with changes in luteal activity in DL14 (Fig 5). 
Table 5. Blood and blow progesterone concentrations $(\mathrm{pg} / \mathrm{ml})$ by sex and reproductive status.

\begin{tabular}{|c|c|c|c|c|c|c|c|c|}
\hline \multirow[b]{2}{*}{ Source } & \multicolumn{4}{|c|}{ Blood Progesterone } & \multicolumn{4}{|c|}{ Blow Progesterone } \\
\hline & $n$ & $\begin{array}{c}\# \\
\text { Samples }\end{array}$ & $\begin{array}{c}\text { Blood } \\
\text { Progesterone } \\
(\text { Mean } \pm \text { SD) }\end{array}$ & $\begin{array}{c}\text { Blood } \\
\text { Progesterone } \\
\text { Range }\end{array}$ & $n$ & $\begin{array}{c}\# \\
\text { Samples }\end{array}$ & $\begin{array}{c}\text { Blow } \\
\text { Progesterone } \\
(\text { Mean } \pm \text { SD) }\end{array}$ & $\begin{array}{c}\text { Blow } \\
\text { Progesterone } \\
\text { Range }\end{array}$ \\
\hline $\begin{array}{c}\begin{array}{c}\text { Female } \\
\text { (all }\end{array} \\
\text { observations) } \\
\end{array}$ & 11 & 64 & $\begin{array}{c}5477.7 \pm \\
12451.1\end{array}$ & $92.9-19873.2$ & 12 & 167 & $266.4 \pm 70.8$ & $143.8-1778.6$ \\
\hline $\begin{array}{l}\text { Adult Female } \\
\text { (Pregnant) }\end{array}$ & 2 & 19 & $\begin{array}{c}10657.2 \pm \\
1362.6\end{array}$ & $\begin{array}{c}5004.3- \\
19873.2\end{array}$ & 3 & 76 & $410.6 \pm 87.8$ & $181.0-1778.6$ \\
\hline $\begin{array}{l}\text { Adult Female } \\
\text { (Non-pregnant, } \\
\text { CL absent) }\end{array}$ & 9 & 35 & $337.8 \pm 159.3$ & $99.3-1017.5$ & 10 & 72 & $242.5 \pm 27.3$ & $143.8-415.3$ \\
\hline $\begin{array}{l}\text { Adult Female } \\
\text { (Pregnancy } \\
\text { unconfirmed, } \\
\text { CL present) }\end{array}$ & 2 & 3 & $6483.9 \pm 2725.0$ & $4557.1-9270.7$ & 3 & 12 & $339.5 \pm 51.0$ & $240.0-417.3$ \\
\hline Juvenile Female & 2 & 7 & $127.8 \pm 38.4$ & $92.9-204.0$ & 2 & 11 & $232.2 \pm 14.2$ & $150.7-385.8$ \\
\hline Male & 0 & 0 & -- & -- & 7 & 19 & $258.6 \pm 42.2$ & $167.0-366.7$ \\
\hline
\end{tabular}

*For whales sampled more than once, means were first determined for each individual; the data displayed is the mean of the individual means. 
Table 6. Correlation between blood and matching blow sample progesterone concentrations. Individual correlations are shown for belugas with $>5$ observations.

\begin{tabular}{cccccc}
\hline ID & Observations & $\begin{array}{c}\text { Linear } \\
\text { Equation }\end{array}$ & $\boldsymbol{R}^{2}$ & $\boldsymbol{F}(\boldsymbol{d} . \boldsymbol{f})$. & $\boldsymbol{p}$ \\
\hline $\begin{array}{c}\text { All sampled } \\
\text { females } \\
(n=11)\end{array}$ & 64 & $\mathrm{y}=0.16 \mathrm{x}+$ & 0.90 & $94.0(1,62)$ & $<0.0001$ \\
\hline DL12 & 14 & $\mathrm{y}=0.12 \mathrm{x}+$ & 0.51 & $14.64(1,12)$ & 0.002 \\
\hline DL14 & 14 & $\mathrm{y}=0.44 \mathrm{x}+$ & 0.38 & $8.98(1,12)$ & 0.01 \\
\hline DL16 & 14 & $\mathrm{y}=0.23 \mathrm{x}+$ & 0.74 & $38.8(1,12)$ & $<0.0001$ \\
\hline DL20 & 6 & $\mathrm{y}=-0.07 \mathrm{x}+$ & 0.03 & $0.14(1,4)$ & 0.73 \\
\hline
\end{tabular}

\section{Discussion}

This study has validated commercially available enzyme immunoassays for testosterone and progesterone in beluga blow samples and has demonstrated that the concentrations of these hormones in beluga blow samples are biologically relevant. Although both progesterone and testosterone have been detected in blow samples collected from other cetacean species, the ability to interpret reproductive hormone concentrations in blow samples has been limited due to a lack of physiological validation. In this study, collecting relatively undiluted blow samples from belugas of known reproductive states allowed for comparisons between samples, establishing the value of progesterone and testosterone determination in beluga blow.

\subsection{Comparison with Blood Samples}

Both testosterone and progesterone concentrations in blow positively correlated with those in blood, demonstrating that blow sample analysis can serve as an indicator of the relative activity of these hormones in circulation. Most individuals sampled repetitively demonstrated 
positive correlations between the two matrices; those that did not either lacked high (DL20) or low (DL3) hormone concentration observations to anchor the regression lines. Therefore, the value of blow sampling is in the ability to make important distinctions between reproductive states (e.g. pregnant vs. non-pregnant) that are associated with relatively large differences in hormone concentrations, as opposed to fine-scale changes in hormone secretion.

The relative amount of testosterone and progesterone in blow compared to matching blood samples (approximately 3-5\%, except for progesterone in non-pregnant females) is approximately half of the relative amount of steroid hormones in human saliva when compared to matching blood measurements (10\%) (Gröschl, 2008). As steroids likely enter saliva via passive diffusion, this similarity in relative concentration supports the hypothesis that steroids also enter the fluid lining the respiratory tract in cetaceans via passive diffusion (Hogg et al., 2009).

\subsection{Biological Relevance of Testosterone Determination in Blow}

Despite the relatively low concentrations observed in this study, testosterone measurements in blow are diagnostically useful. While there is a high degree of overlap between out of season adult males, juvenile males, and females at low testosterone concentrations, high testosterone concentrations can be used to identify adult male belugas, especially during the breeding season. However, testosterone concentrations in blow can still be informative outside of the breeding season, as evidenced by the analysis of wild beluga samples collected in late summer for this study. The seasonal variation in testosterone secretion in belugas reduces, but does not eliminate, the value of blow sampling as a diagnostic tool for identifying adult males outside of the breeding season. 
Given the low testosterone concentrations found in both immature males and females, as well as the low blow testosterone to blood testosterone ratio, this method is currently insufficiently sensitive to reliably differentiate juvenile males from females in this species. However, the three highest testosterone concentrations found in female samples were the only pregnant female samples assayed for testosterone. Testosterone has also been detected in presumed pregnant humpback whale blow samples (Hogg et al., 2009). However, the two female belugas sampled in Bristol Bay for this study were presumed pregnant based on blood progesterone values (data not shown), yet their blow testosterone concentrations were in the range of the negative controls. Because approximately $1 / 3$ of female belugas are pregnant in wild populations (Burns and Seaman, 1988), it will be important to sample additional pregnant females to determine if measuring testosterone in blow from beluga females can be used as a diagnostic indicator of pregnancy.

\subsection{Biological Relevance of Progesterone Determination in Blow}

Progesterone measurements in blow reflected reproductive cycle stage in female belugas, with detectable increases in progesterone with the onset of pregnancy or the presence of a corpus luteum in individual females monitored longitudinally. Although an increase in progesterone would be expected with these reproductive events, the relative increase in progesterone in blow with pregnancy state did not match those found in blood samples from this study or others (Robeck et al., 2005; Stewart, 1994). While pregnancy resulted in more than a 30-fold increase in blood progesterone concentration, progesterone in blow only increases by a factor of 1.7, perhaps due to the inability of the steroid to accumulate in the fluid lining the respiratory tract. The lack of proportionality reduces the value of any one sample, especially when compared to 
other matrices, where distinctions between states are clearer (Kellar et al., 2013a; Rolland et al., 2005). Despite some ambiguity, most samples would be informative, as there was a diagnostically useful threshold $(>330 \mathrm{pg} / \mathrm{ml})$ that indicated pregnancy with reasonable certainty ( $80 \%$ of cases, with a low false positive rate in this study). Blow sampling may also be used to detect ovulation, although repeated sampling would be necessary to discriminate between a nonconceptive cycle and a pregnancy. The time of year that the samples are collected would further resolve this uncertainty, as estrous cycles are rare from July through December (Robeck et al., 2005). Additional sampling is required to fully develop the diagnostic value of this method.

Progesterone concentrations in blow were not valuable in determining the sex of the beluga in the absence of pregnancy or luteal activity. Given the low concentrations of progesterone in blood for non-pregnant adults and juvenile females, this method is also not sensitive enough to detect maturity in females unless there is luteal activity or an ongoing pregnancy. This was also the case for progesterone measurements in the blubber of several other odontocete species (Trego et al., 2013).

\subsection{Other factors influencing hormone concentrations in blow}

In addition to reproductive status, other physiological factors may influence testosterone concentration in blow, including diurnal rhythm (Funasaka et al., 2011), stress (Lynn et al., 2015) or contaminant load (Oskam et al., 2003; Subramanian et al., 1987). Hormone concentrations in blow samples are also affected by the sampling procedure. The belugas in this study exhaled once to clear away pooled water from their blowhole, but the volume of water remaining on or around the blowhole likely varied from sample to sample, which may have caused some of the variation in blow hormone concentrations within groups found in this study. 
As recognized by others studying cetacean blow samples (Hogg et al., 2009; Hunt et al., 2014; Thompson et al., 2014), the most significant limitation to the application of this methodology to free-swimming cetaceans is dilution from environmental water. Increased risk for water contamination during sample collection in Bristol Bay may have led to low testosterone concentrations in male blow samples and obscured the correlation between blood and blow that was found to occur in aquarium belugas. However, all of the wild male samples fell within the range of testosterone concentrations found in aquarium beluga samples collected in the summer or fall. Increasing sample size will aid in determining if testosterone in blow is correlated with testosterone in blood in wild belugas as it is in aquarium belugas.

While the collection material selected did result in relatively low levels of non-specific binding, all of the samples used in this study were collected in the same way, and validation experiments demonstrate that this effect was consistent across samples, allowing comparisons between samples for the purposes of this study. The nylon mesh used in this study was selected based on its performance with a Cayman Chemical cortisol EIA kit with beluga blow samples (Thompson et al., 2014). Various materials that have previously been used to collect blow samples have been shown to introduce consistent levels of assay interference ("background noise") across hormone concentrations in mock blow samples (without the biological matrix) (Burgess et al., 2016). The levels of non-specific binding found in the testosterone and progesterone negative control samples in this study were similar to those reported by Burgess et al. (2016) for those hormones applied to the same nylon mesh material. The relatively high amount of progesterone in blow samples collected from non-pregnant females is likely due to this effect, which is amplified in samples collected from belugas with low blood progesterone 
concentrations. Eliminating or reducing this non-specific binding would improve the diagnostic value of the method, especially at lower concentrations.

\subsection{Application to unrestrained wild belugas}

In order for hormone determination in blow to be applied to wild, free-swimming belugas, a single exhale should contain enough sample to perform the assay, as collecting multiple exhales from an unrestrained whale is unlikely. In a majority of the cases in this study, a single exhale would have yielded a large enough fluid volume (55 $\mu 1)$ to perform the assay at a 1:2 dilution. With additional validation experiments, the sensitivity of this assay would allow for samples to be diluted even further prior to analysis, requiring as little as $10 \mu 1$ of sample.

The hormone concentration should also not vary significantly from exhale to exhale, so that conclusions can be drawn from the analysis of the blow sample that is collected. The comparison of samples consisting of the $1^{\text {st }}, 3^{\text {rd }}$, and $5^{\text {th }}$ or the $2^{\text {nd }}, 4^{\text {th }}$, and $6^{\text {th }}$ exhales suggest that the hormone concentrations vary little from breath to breath when there is not a long breath hold in between exhales. Further experiments on belugas in aquaria can be conducted to determine the effect of breath hold (dive) duration on hormone concentration in blow for improved application to wild belugas that may be sampled upon surfacing from a dive.

Sampling in field conditions also requires that samples be stored appropriately until analysis. Several sample handling experiments demonstrated that testosterone in blow is stable both during temporary storage while chilled and long term storage while frozen. Thus, we can be confident that the storage protocols in this study do not affect the interpretation of testosterone concentrations. 
In addition to the ability to accurately measure hormones in blow, the reproductive state of an unknown beluga should ideally be distinguished from a single sample. Sampling a larger number of belugas in various reproductive states would allow for the development of statistical models that could be used to determine the probability that an unknown beluga is in a particular reproductive state based on hormone determinations in blow. Although the number of belugas in this study was small, this sample represents $>60 \%$ of the belugas in US aquaria, including all of the living sires (Myers, 2014). The closely managed beluga breeding program in US aquaria will allow for increased sampling with greater frequency in the future.

\subsection{Current Utility of Testosterone and Progesterone Determination in Beluga Blow Samples}

An important advantage of blow sampling in aquaria is the relative ease with which samples can be collected relative to blood samples. Blow sampling will enable frequent longitudinal monitoring of individuals, improving reproductive management and creating new research opportunities. For wild belugas, this method is immediately applicable to mass stranding events such as those that occur in Cook Inlet, Alaska, where groups of belugas may temporarily strand between high tides, eliminating the chance of water contamination of the sample. One such event involved the live, temporary stranding of at least 76 belugas, representing nearly a quarter of the 315 belugas estimated to comprise that stock (National Marine Fisheries Service, 2015). Blow sampling would strike a balance between minimizing the stress of handling imposed on the animals while they are already under stress and maximizing the information that could be obtained during these events.

The ability to identify pregnant females non-invasively in Cook Inlet would be a great benefit to population management. A significant effort is made in this population to identify 
individuals and to count calves during aerial censuses; having the ability to identify pregnant females and follow up on her success at birthing and rearing the calf would help identify potential causes for the lack of recovery in this population (National Marine Fisheries Service, 2015). The ability to identify males in breeding condition is also important, as reduced availability of breeding males can negatively impact population viability (Milner et al., 2007). Additionally, detecting maturity in belugas is difficult to perform through visual inspection alone; an improved understanding of the proportion of belugas that are mature through the use of blow sampling would aid in developing more accurate population models (Mosnier et al., 2015). Detecting when males and females are reproductively active through testosterone and progesterone determination would help clarify when conceptions are occurring and thus identify periods when wild beluga populations may be more vulnerable to disturbance. In conjunction with photo identification of individuals and aerial surveys, blow sampling temporarily stranded individuals would allow for better management of endangered populations, such as the Cook Inlet stock.

Additional research is required for blow sampling to provide the same diagnostic capabilities as biopsy sampling in free-swimming cetaceans. However, the perceived risks associated with biopsy sampling may preclude research from being conducted or limit sampling capabilities. With further development, blow sampling will provide a less invasive, yet informative alternative for monitoring population demographics and viability.

\section{Conclusion}

This study advances the use of cetacean blow samples for hormone determination by demonstrating that testosterone and progesterone concentrations in beluga blow samples are 
biologically relevant, varying by sex, maturity status, season, and reproductive cycle stage. The positive correlation between testosterone and progesterone in blow and blood found in this study is an important step in the development of cetacean blow sampling as a diagnostic tool for studying population demographics, and further justifies the continued study of other analytes that can be detected in blow samples. Continued validation experiments and method development using samples collected from cetaceans in aquaria will improve the application of blow sampling to wild cetaceans. This study provides a framework for interpreting testosterone or progesterone concentrations found in blow samples, which can be used to monitor breeding in aquaria, as well as to identify pregnant females or males in breeding condition in wild belugas that are temporarily stranded. This technique holds promising management and conservation applications for threatened or endangered whales such as the Cook Inlet beluga population.

\section{Acknowledgements}

This research is made possible by the beluga training and veterinary staffs at the Mystic Aquarium (especially Kristine Magao, Lindsey Nelson, Kate McElroy, Carey Richard, Allison Tuttle and Allyson McNaughton), Georgia Aquarium (especially the beluga care team, veterinary technicians, Cara Field and Tonya Clauss), SeaWorld San Antonio (especially Shannon Bond, Carley Lindgren, Kristen Werner, Kristie McCann, Steve Aibel, and Sherry Dickerson), and Shedd Aquarium (especially Lisa Takaki, Maris Muzzy and Frank Oliaro). Special thanks to Mandy Keogh and Laura Thompson for their guidance, and to Crysania Brady and Renee Bakker for laboratory assistance. J. Lawrence Dunn provided helpful comments on the manuscript. Bristol Bay beluga sampling was made possible through the support of the Georgia Aquarium, Bristol Bay Marine Mammal Council, and the Bristol Bay field team and 
boat captains, especially Rod Hobbs and Caroline Goertz. Funding: This project was supported by funding from the Marine Mammal Commission, the Sea Research Foundation, SeaWorld, and the University of Rhode Island Enhancement of Graduate Research Award. This material is based upon work supported by the National Science Foundation Graduate Research Fellowship awarded to JTR under Grant No. 1244657. This is SeaWorld technical contribution number 2016-08-C. This constitutes scientific contribution \#271 from the Sea Research Foundation. 


\section{References}

Amaral, R.S., 2010. Use of alternative matrices to monitor steroid hormones in aquatic mammals: a review. Aquat. Mamm. 36, 162-171.

Bates, D., Maechler, M., Bolker, B., Walker, S., 2015. Fitting linear mixed-effects models using lme4. J. Stat. Softw. 67, 1-48.

Burgess, E.A., Hunt, K.E., Kraus, S.D., Rolland, R.M., 2016. Get the most out of blow hormones: validation of sampling materials, field storage and extraction techniques for whale respiratory vapour samples. Conserv. Physiol. 4, cow024.

Burns, J.J., Seaman, G.A., 1988. Investigations of belukha whales in coastal waters of western and northern Alaska. II. Biology and ecology. U.S. Dept. Commerce, Final Report Submitted to NOAA, Outer Continental Shelf Environmental Assessment Program, 56, 221-357.

Dunstan, J., Gledhill, A., Hall, A., Miller, P., Ramp, C., 2012. Quantification of the hormones progesterone and cortisol in whale breath samples using novel, non-invasive sampling and analysis with highly-sensitive ACQUITY UPLC and Xevo TQ-S. Waters Corporation Application Note, Manchester, UK. 8 p.

Fox, J., 2003. Effect displays in R for generalized linear models. J. Stat. Softw. 8(15), 1-9.

Funasaka, N., Yoshioka, M., Suzuki, M., Ueda, K., Miyahara, H., Uchida, S., 2011. Seasonal difference of diurnal variations in serum melatonin, cortisol, testosterone, and rectal temperature in Indo-Pacific bottlenose dolphins (Tursiops aduncus). Aquat. Mamm. 37, 433-442.

Green, M.L., Herzing, D.L., Baldwin, J.D., 2007. Noninvasive methodology for the sampling and extraction of DNA from free-ranging Atlantic spotted dolphins (Stenella frontalis). Mol. Ecol. Notes 7, 1287-1292.

Gröschl, M. 2008. Current status of salivary hormone analysis. Clin. Chem. 54, 1759-1769.

Heide-Jørgensen, M.P., Teilmann, J., 1994. Growth, reproduction, age structure and feeding habits of white whales (Delphinapterus leucas) in West Greenland waters. Bioscience 39, 195212.

Hobbs, R.C., Wade, P.R., Shelden, K.E.W., 2015. Viability of a small, geographically-isolated population of beluga whales, Delphinapterus leucas: Effects of hunting, predation, and mortality events in Cook Inlet, Alaska. Mar. Fish. Rev. 77, 59-88.

Hogg, C.J., Vickers, E.R., Rogers, T.L., 2005. Determination of testosterone in saliva and blow of bottlenose dolphins (Tursiops truncatus) using liquid chromatography-mass spectrometry. J. Chromatogr. B 814, 339-346. 
Hogg, C.J., Rogers, T.L., Shorter, A., Barton, K., Miller, P.J.O., Nowacek, D., 2009.

Determination of steroid hormones in whale blow: It is possible. Mar. Mamm. Sci. 25, 605-618.

Høier, R., Heide-Jørgensen, M.P., 1994. Steroid hormones and prolactin in white whales (Delphinapterus leucas) from West Greenland. Bioscience 39, 227-238.

Hunt, K.E., Moore, M.J., Rolland, R.M., Kellar, N.M., Hall, A.J., Kershaw, J., Raverty, S.A., Davis, C.E., Yeates, L.C., Fauquier, D.A., Rowles, T.K., Kraus, S.D., 2013. Overcoming the challenges of studying conservation physiology in large whales: a review of available methods. Conserv. Physiol. 1, cot006.

Hunt, K.E., Rolland, R.M., Kraus, S.D., 2014. Detection of steroid and thyroid hormones via immunoassay of North Atlantic right whale (Eubalaena glacialis) respiratory vapor. Mar. Mamm. Sci. 30, 796-809.

Kellar, N.M., Keliher, J., Trego, M.L., Catelani, K.N., Hanns, C., George, J.C., Rosa, C., $2013 a$. Variation of bowhead whale progesterone concentrations across demographic groups and sample matrices. Endanger. Species Res. 22, 61-72.

Kellar, N.M., Trego, M.L., Chivers, S.J., Archer, F.I., 2013b. Pregnancy patterns of pantropical spotted dolphins (Stenella attenuata) in the eastern tropical Pacific determined from hormonal analysis of blubber biopsies and correlations with the purse-seine tuna fishery. Mar. Biol. 160, 3113-3124.

Kellar, N.M., Trego, M.L., Chivers, S.J., Archer, F.I., Perryman, W.L., 2014. From progesterone in biopsies to estimates of pregnancy rates: Large scale reproductive patterns of two sympatric species of common dolphin, Delphinus spp. off California, USA and Baja, Mexico. Bull. South. Calif. Acad. Sci. 113, 58-80.

Kellar, N.M., Trego, M.L., Marks, C.I., Chivers, S.J., Danil, K., Archer, F.I., 2009. Blubber testosterone: a potential marker of male reproductive status in short-beaked common dolphins. Mar. Mamm. Sci. 25, 507-522.

Kersey, D.C., Dehnhard, M., 2014. The use of noninvasive and minimally invasive methods in endocrinology for threatened mammalian species conservation. Gen. Comp. Endocrinol. 203, 296-306.

Labrada-Martagón, V., Zenteno-Savín, T., Mangel, M., 2014. Linking physiological approaches to marine vertebrate conservation: using sex steroid hormone determinations in demographic assessments. Conserv. Physiol. 2, cot035.

Lynn, S.E., Perfito, N., Guardado, D., Bentley, G.E., 2015. Food, stress, and circulating testosterone: Cue integration by the testes, not the brain, in male zebra finches (Taeniopygia guttata). Gen. Comp. Endocrinol. 215, 1-9. 
Milner, J.M., Nilsen, E.B., Andreassen, H.P., 2007. Demographic side effects of selective hunting in ungulates and carnivores. Conserv. Biol. 21, 36-47.

Mosnier, A., Doniol-Valcroze, T., Gosselin, J-F., Lesage, V., Measures, L.N., Hammill, M.O., 2015. Insights into processes of population decline using an integrated population model: the case of the St. Lawrence Estuary beluga (Delphinapterus leucas). Ecol. Model. 314, 15-31.

Myers, T., 2014. AZA Regional Studbook: Beluga Whale (Delphinapterus leucas). https://www.aza.org/studbooks/ (accessed 15.08.01)

National Marine Fisheries Service, 2015. Draft Recovery Plan for the Cook Inlet Beluga Whale (Delphinapterus leucas). National Marine Fisheries Service, Alaska Regional Office, Protected Resources Division, Juneau, AK.

Norman, S.A., Goertz, C.E.C., Burek, K.A., Quakenbush, L.T., Cornick, L.A., Romano, T.A, Spoon, T., Miller, W., Beckett, L.A., Hobbs, R.C., 2012. Seasonal hematology and serum chemistry of wild beluga whales (Delphinapterus leucas) in Bristol Bay, Alaska, USA. J. Wildlife Dis. 48, 21-32.

Oskam, I.C., Ropstad, E., Dahl, E., Lie, E., Derocher, A.E., Wiig, Ø., Larsen, S., Wiger, R., Skaare, J.U., 2003. Organochlorines affect the major androgenic hormone, testosterone, in male polar bears (Ursus maritimus) at Svalbard. J. Toxicol. Environ. Health A 6, 2119-2139.

Pérez, S., Garcia-López, Á., De Stephanis, R., Giménez, J., García-Tiscar, S., Verborgh, P., Mancera, J.M., Martínez-Rodriguez, G., 2011. Use of blubber levels of progesterone to determine pregnancy in free-ranging live cetaceans. Mar. Biol. 158, 1677-1680.

R Core Team., 2015. R: A language and environment for statistical computing. R Foundation for Statistical Computing, Vienna, Austria. http://www.R-project.org

Robeck, T.R., Monfort, S.L., 2006. Characterization of male killer whale (Orcinus orca) sexual maturation and reproductive seasonality. Theriogenology 66, 242-250.

Robeck, T.R., Monfort, S.L., Calle, P.P., Dunn, J.L., Jensen, E., Boehm, J.R., Young, S., Clark, S.T., 2005. Reproduction, growth and development in captive beluga (Delphinapterus leucas). Zoo Biol. 24, 29-49.

Robeck, T.R., Schmitt, T.L., Osborn, S., 2015. Development of predictive models for determining fetal age-at-length in belugas (Delphinapterus leucas) and their application toward in situ and ex situ population management. Mar. Mamm. Sci. 31, 591-611.

Robeck, T.R., Steinman, K.J., Montano, G.A., Katsumata, E., Osborn, S., Dalton, L., Dunn, J.L., Schmitt, T., Reidarson, T., O’Brien, J.K., 2010. Deep intra-uterine artificial inseminations using cryopreserved spermatozoa in beluga (Delphinapterus leucas). Theriogenology 74, 989-1001. 
Rolland, R.M., Hunt, K.E., Kraus, S.D., Wasser, S.K., 2005. Assessing reproductive status of right whales (Eubalaena glacialis) using fecal hormone metabolites. Gen. Comp. Endocrinol. $142,308-317$.

Steinman, K.J., O’Brien, J.K., Monfort, S.L., Robeck, T.R., 2012. Characterization of the estrous cycle in female beluga (Delphinapterus leucas) using urinary endocrine monitoring and transabdominal ultrasound: evidence of facultative induced ovulation. Gen. Comp. Endocrinol. $175,389-397$.

Stewart, R.E.A., 1994. Progesterone levels and reproductive status of white whales (Delphinapterus leucas) from the Canadian Arctic. Bioscience 39, 239-243.

Subramanian, A.N., Tanabe, S., Tatsukawa, R., Saito, S., Miyazaki, N., 1987. Reduction in the testosterone levels by PCBs and DDE in Dall's porpoises of the Northwestern North Pacific. Mar. Pollut. Bull. 18, 643-646.

Suydam, R., 2009. Age, growth, reproduction, and movements of beluga whales (Delphinapterus leucas) from the eastern Chukchi Sea. University of Washington Dissertation.

http://www.alaskafisheries.noaa.gov/protectedresources/whales/beluga/reproduction/suydam_dis sertation2009.pdf

Thompson, L.A., Spoon, T.R., Goertz, C.E., Hobbs, R.C., Romano, T.A., 2014. Blow collection as a non-invasive method for measuring cortisol in the beluga (Delphinapterus leucas). PLoS One 9, e114062.

Tizzi, R., Accorsi, P.A., Azzali, M., 2010. Non-invasive multidisciplinary approach to the study of reproduction and calf development in bottlenose dolphin (Tursiops truncatus): the Rimini Delfinario experience. Int. J. Comp. Psychol. 23, 734-776.

Trego, M.L., Kellar, N.M., Danil, K., 2013. Validation of blubber progesterone concentrations for pregnancy determination in three dolphin species and a porpoise. PLoS ONE 8, e69709. 


\section{Figure Captions}

Fig. 1. Seasonal testosterone variation in adult male blow samples. Open circles: individual observations. Closed circles: monthly average. Regression line: quartic polynomial regression line.

Fig. 2. Untransformed blow testosterone concentrations by reproductive status, with observations of nylon spiked with assay buffer serving as negative controls. Points represent individual observations, with marker varied by individual for male belugas.

Fig. 3. Untransformed blow progesterone concentrations by sex and reproductive status, with observations of nylon spiked with assay buffer serving as negative controls. Points represent individual observations, with marker varied by individual for female belugas. To improve visualization, two outlying observations for pregnant females are not plotted in this graph (1088.7 and $1778.6 \mathrm{pg} / \mathrm{ml})$.

Fig. 4. Longitudinal changes in blow progesterone concentrations in individual belugas that were pregnant during the study period. To improve visualization, two outlying observations for DL12 during pregnancy are not plotted in this graph (1088.7 and $1778.6 \mathrm{pg} / \mathrm{ml})$.

Fig. 5. Progesterone concentrations in blow from DL14 for samples collected while a corpus luteum was present $(326.5 \pm 33.3)$ or absent $(248.5 \pm 62.5)$, as detected via ultrasound. 


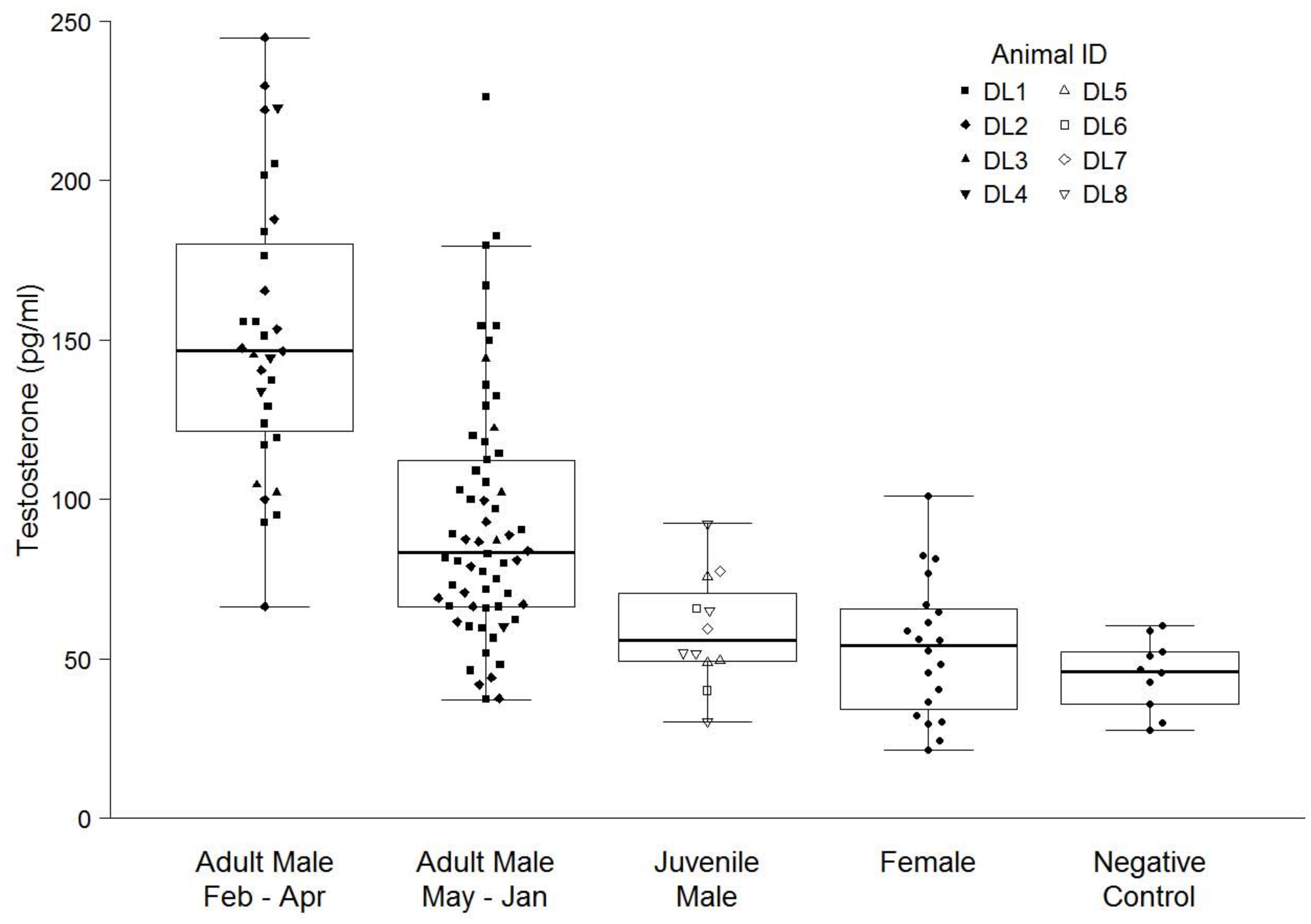




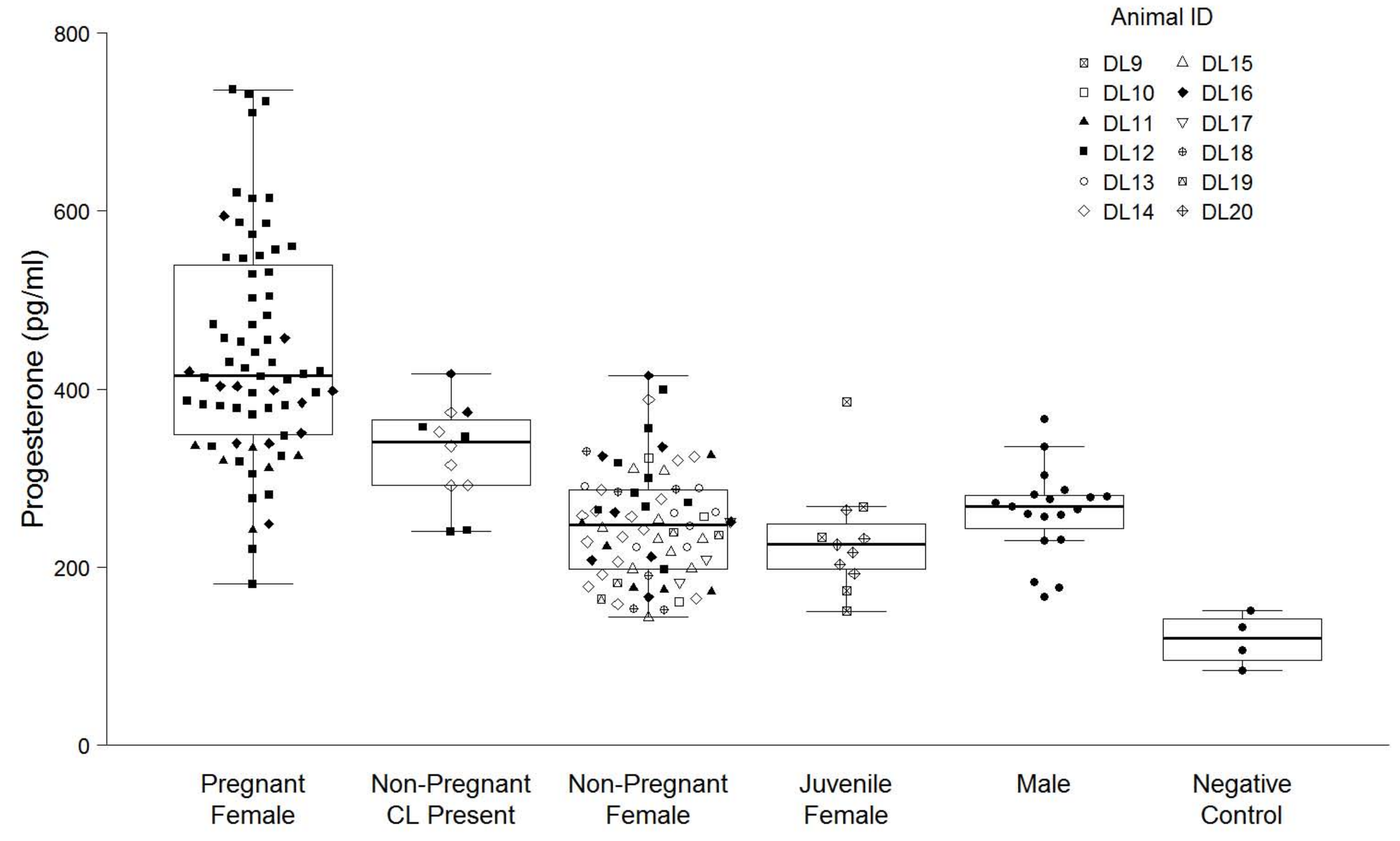




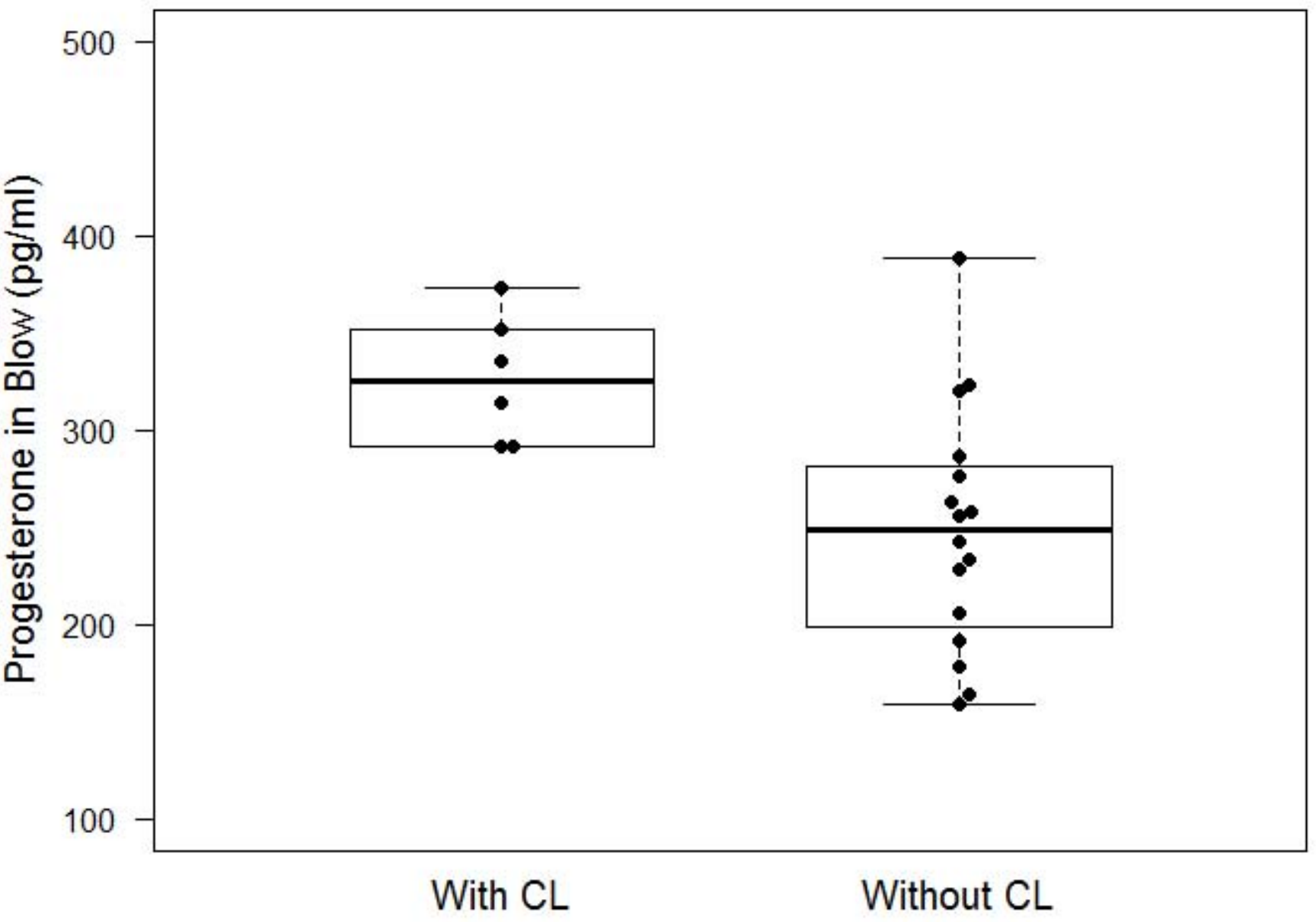

